\title{
Pengembangan Plugin Eduplayer pada E-Learning untuk Meningkatkan Kompetensi Animasi Mahasiswa
}

\author{
Afis Pratama ${ }^{1}$ \\ ${ }^{1}$ IKIP Veteran Jawa Tengah \\ Semarang, Indonesia \\ afistama@gmail.com
}

\begin{abstract}
Abstrak
Electronic Learning atau yang disingkat e-learning telah banyak digunakan dalam dunia pendidikan saat ini karena dapat digunakan untuk membantu proses transformasi paradigma pembelajaran dari teacher-centered menuju student-centered. Selain itu, e-learning memiliki fiturfitur yang dapat digunakan tenaga pengajar untuk menunjang kegiatan pembelajaran seperti video streaming, virtual laboratory, virtual library, self assessment dan sebagainya. Dalam mata kuliah berbasis praktik, penggunaan video tutorial pada e-learning dirasa perlu sebagai sumber belajar alternatif. Hal ini dikarenakan video tutorial mampu menampilkan pembelajaran tertentu secara berulang-ulang sesuai keinginan pengguna.

Tujuan jangka pendek dalam penelitian ini adalah untuk membuat video tutorial yang layak sebagai sumber belajar alternatif dalam mata kuliah Desain Grafis, dimana video tutorial yang telah dibuat nantinya akan disematkan pada e-learning IKIP Veteran Jawa Tengah dan diharapkan mampu untuk meningkatkan pemahaman mahasiswa setelah menggunakan video tutorial yang terdapat pada $e$ learning. Tujuan jangka panjang penelitian ini adalah mampu untuk menciptakan macam-macam video tutorial pada e-learning dalam mata kuliah lainnya yang berbasis praktik dan memperkaya konten e-learning itu sendiri. Hasil dari penelitian ini menunjukkan mahasiswa sangat tertarik dengan adanya video tutorial pada e-learning IKIP Veteran dan video tutorial tersebut juga mampu meningkatkan hasil belajar siswa.
\end{abstract}

Kata Kunci: e-learning, Video Tutorial, Desain Grafis, Sumber Belajar Alternatif.

\begin{abstract}
E-learning has been widely used in the world of education today because it can be used to help the process of transforming the paradigm of learning from teacher-centered to student-centered. In addition, e-learning has features that teachers can use to support learning activities such as video streaming, virtual laboratory, virtual library, self assessment and so on. In practice-based courses, the use of video tutorials on e-learning is considered necessary as an alternative learning resource. This is because video tutorials are able to display certain lessons repeatedly according to the user's wishes.

The short-term goal in this study is to make a decent video tutorial as an alternative learning resource in Graphic Design course, where the tutorial video that has been created will be pinned on elearning IKIP Veteran Central Java and is expected to improve students' understanding after using video tutorial contained in e-learning. The long-term goal of this research is to be able to create various video tutorials on e-learning in other courses that are practice-based and enrich the content of e-learning itself. The result of this research shows that the students are very interested with the video tutorial on IKIP Veteran e-learning and the tutorial video is also able to improve student learning outcomes.

Keywords: e-learning, Video Tutorials, Graphic Design, Alternative Learning Resources.
\end{abstract}




\section{PENDAHULUAN}

Perkembangan teknologi yang semakin inovatif saat ini memberikan dampak yang sangat baik pada dunia pendidikan. Salah satu inovasi dalam dunia pendidikan adalah pemanfaatan e-learning. Saat ini e-learning telah banyak digunakan oleh institusi pendidikan karena dapat diakses dari mana saja dan kapan saja oleh peserta kuliah. Mereka juga mulai menambah berbagai macam fitur untuk lebih menghidupkan $e$ learning ini, diantaranya fasilitas video streaming, virtual laboratory, virtual library, dan fitur lainnya. Melihat manfaatnya yang besar ke depan, maka layanan ini dapat menjadi daya tarik pada perguruan tinggi dan sebagai branding yang dapat mengangkat citra dan image perguruan tinggi di masyarakat sebagai kampus cyber.

Seiring dengan perkembangan $e$ learning maka vendor pengembang sistem yang bersifat opensource marak bermunculan seperti Moodle, Dokeos, Sakai, Schoology, Edmodo dan sebagainya. Perkembangan sistem berbasis opensource cukup pesat karena kecilnya investasi sistem e-learning. Investasi yang dimaksud adalah hardware dan software bila dibandingkan dengan pembelajaran dengan cara konvensional (Suteja \& Dkk, 2010). Beberapa perguruan tinggi baik di Indonesia dan juga di luar negri telah banyak menerapkan sistem e-learning ini.

Salah satu tren teknologi yang sedang digemari oleh masyarakat saat ini adalah video. Video adalah teknologi yang mampu menangkap, merekam, memproses, mentransmisikan dan menata ulang gambar bergerak. Dengan kemampuannya tersebut, video dapat digunakan sebagai penunjang perkuliahan. Dalam mata kuliah Desain Grafis, video yang bersifat tutorial dirasa perlu untuk menunjang aktivitas pembelajaran, karena materi-materi dalam perkuliahan Desain Grafis tidak semuanya mampu disampaikan melalui ceramah dosen maupun modul yang ada. Lebih lagi, tutorial online dapat mengemas ulang informasi dengan cara yang berbeda dari instruksi tatap muka di kelas. (Hebert \& Roberts, 2013).

E-learning di kampus IKIP Veteran Semarang (ELIV) memiliki konten-konten menarik yang mampu mendukung kegiatan perkuliahan. Namun konten video sebagai penunjang aktivitas perkuliahan, belum dimanfaatkan oleh para dosen di IKIP Veteran Semarang. Konten video sebenarnya mampu menjadi solusi ketika sebuah materi sulit untuk disampaikan melalui metode ceramah karena mampu menampilkan tontonan sebuah materi dan juga cara praktik tahap demi tahap di dalamnya.

Dalam penelitian ini, peneliti ingin mengembangkan tiga buah video tutorial sebagai sumber belajar alternatif untuk mata kuliah desain grafis. Dalam proses pengembangannya nanti, video yang dibuat akan diuji kelayakannya oleh seorang ahli media pembelajaran. Selanjutnya video akan disematkan pada e-learning. Setelah itu, akan menganalisa tentang respon dan tingkat pemahaman mahasiswa setelah menggunakan video tutorial yang ada pada e-learning.

\section{METODE PENELITIAN}

Model penelitian ini menggunakan model research and development (R\&D). Tahapan penelitian R\&D terdiri dari 9 langkah (Sugiyono, 2013) antara lain : (1) Potensi dan masalah, (2) Studi Literatur dan Pengumpulan data, (3) Desain video tutorial, (4) Validasi desain, (5) Revisi desain, (6) Uji Coba Terbatas video, (7) Revisi video, (8) Uji Coba video skala lebih luas, dan (9) Revisi akhir video. Secara skematik tahapan-tahapan tersebut ditunjukkan pada gambar berikut.

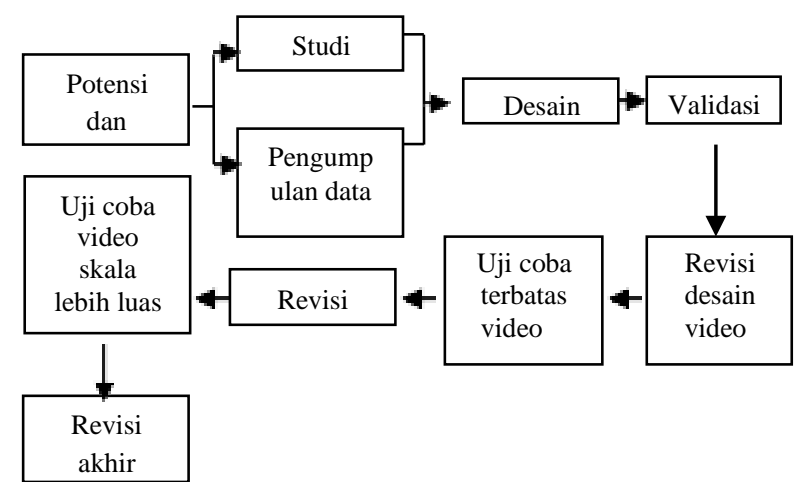

Gambar 1. Tahapan Penelitian 
Penelitian ini dilakukan di IKIP Veteran Jawa Tengah. Waktu pelaksanaan pada semester ganjil tahun ajaran 2017/2018 pada mahamahasiswa semester 3 jurusan Pendidikan Informatika yang berjumlah 26 orang. Subjek penelitian dalam penelitian ini adalah mahasiswa Pendidikan Informatika di IKIP Veteran Jawa Tengah yang berjumlah 26 orang.

Teknik pengumpulan data yang digunakan meliputi:

a. Metode Observasi

Metode ini digunakan untuk mengetahui keadaan pembelajaran Desain grafis di IKIP Veteran Jawa Tengah. Data yang diperoleh merupakan hasil wawancara kepada guru teknik komputer dan jaringan.

b. Metode Tes

Metode tes ini merupakan tes hasil belajar mahasiswa untuk mengetahui hasil karakteristik kognitif setelah menggunakan video tutorial pada e-learning.

c. Lembar Angket

Metode ini digunakan untuk mengetahui kualitas video tutorial pada e-learning, yang akan ditujukan kepada seorang ahli media pembelajaran.

\section{HASIL PENELITIAN}

\section{Hasil Video Tutorial}

Video tutorial yang disematkan pada e-learning IKIP Veteran menjelaskan langkah demi langkah tentang materi yang dibahas. Video yang dibuat dan disematkan pada elearning IKIP Veteran Jawa tengah meliputi:

a. Video tutorial membuat teks 3D

b. Video tutorial tracing image

c. Video tutorial membuat logo

Mahasisiwa dapat mengakses video langsung di mata kuliah Desain Grafis yang terdapat di e-learning IKIP Veteran Jawa Tengah.

Data dari penyebaran angket tentang ketertarikan mahasiswa terhadap video tutorial yang ada di e-learning menunjukkan $62 \%$ mahasiswa sangat tertarik dan $28 \%$ mahasiswa tertarik terhadap adanya video tutorial pada elearning IKIP Veteran Jawa Tengah.

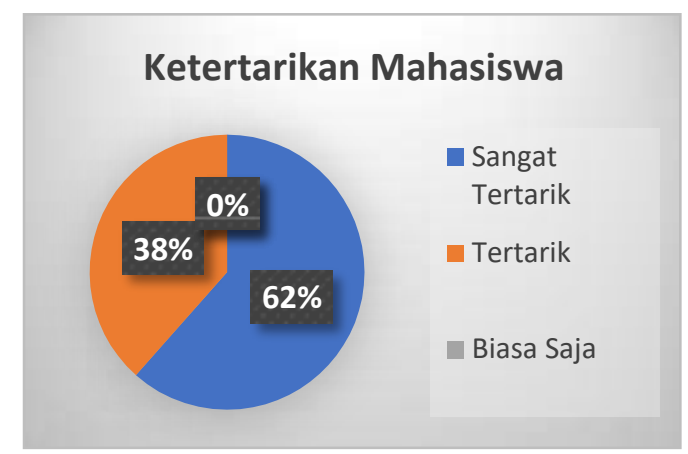

Gambar 2. Data ketertarikan mahasiswa

\section{Peningkatan Hasil Belajar Siswa}

Sedangkan data untuk keefektifan video tutorial pada e-learning menunjukkan bahwa video tutorial mampu meningkatkan hasil belajar siswa. Pre-test dan post-test dilakukan kepada mahasiswa jurusan Pendidikan Informatika. Pengujian dilakukan secara dua tahap, yakni ujicoba terbatas dan ujicoba skala lebih luas. Pada ujicoba terbatas pengujian dilakukan kepada 10 siswa dan pada uji skala lebih luas dilakukan pengujian terhadap 26 siswa. Analisis perbedaan hasil belajar siswa dilaksanankan untuk mengetahui apakah ada penguatan hasil belajar siswa dengan adanya video tutorial di e-learning IKIP Veteran. Data yang digunakan dalam analisa perbedaan rata-rata hasil belajar siswa adalah data nilai pre-test siswa dan data nilai post-test siswa setelah menggunaan video tutorial.

Tabel 1. Hasil Pre-Test dan Post-Test

\begin{tabular}{|c|c|c|c|c|c|c|}
\hline \multirow{2}{*}{ Indikator } & \multicolumn{3}{|c|}{ Ujicoba Terbatas } & \multicolumn{3}{|c|}{$\begin{array}{l}\text { Ujicoba Skala Lebih } \\
\text { Luas }\end{array}$} \\
\hline & $\begin{array}{l}\text { Pre- } \\
\text { Test }\end{array}$ & $\begin{array}{l}\text { Post- } \\
\text { Test }\end{array}$ & Gain & $\begin{array}{l}\text { Pre- } \\
\text { Test }\end{array}$ & $\begin{array}{l}\text { Post- } \\
\text { Test }\end{array}$ & Gain \\
\hline $\begin{array}{l}\text { 1. Memahami } \\
\text { pembuatan } \\
\text { text 3D }\end{array}$ & 20 & 30 & 10 & 20.5 & 31 & 10.5 \\
\hline $\begin{array}{l}\text { 2. Memahai } \\
\text { cara trace } \\
\text { image }\end{array}$ & 20.5 & 26.25 & 5.75 & 21 & 25.1 & 4.1 \\
\hline $\begin{array}{l}\text { 3. Memahami } \\
\text { cara } \\
\text { pembuatan } \\
\text { logo }\end{array}$ & 20 & 26.25 & 6.25 & 21.1 & 25 & 3.9 \\
\hline Total & $\underline{60.5}$ & $\underline{82.5}$ & 22 & 62.6 & $\underline{81.1}$ & 18.5 \\
\hline
\end{tabular}


Berdasarkan data diatas, dapat dilihat adanya peningkatan hasil belajar sebelum dan sesudah menggunakan media pembelajaran. Analisa dari hasil ujicoba skala lebih luas menunjukkan adanya gain sebesar 18,5. Alat bantu dalam proses analisa menggunakan bantuan software SPSS 20, analisis perbedaan hasil belajar dilakukan dengan menggunakan uji-t sampel berpasangan (paired sample t-test) karena seluruh data berdistribusi normal, serta variansinya homogen. Hasil yang didapat dari signifikansi 2-tailed sebesar 0.000. Jika nilai tersebut dibandingkan dengan nilai $\alpha=0.05 \%$ (5\%) maka nilai signifikansi 2-tailed $<\alpha$. Pengujian kedua yaitu dengan membandingkan $\mathrm{t}$ hitung dengan $\mathrm{t}$ tabel. Analisa ini dimaksudkan untuk mengetahui ada tidaknya perbedaan yang signifikan antara nilai pre-test dan post-test. Uji hipotesis yaitu hipotesis nol $\left(\mathrm{H}_{0}\right)$ dengan kriteria pengujian sebagai berikut:

- $\mathrm{H}_{0}$ ditolak jika $\mathrm{t}_{\text {hitung }}>\mathrm{t}_{\text {tabel: }}$ terjadi perubahan yang signifikan pada skor siswa setelah ada perlakuan tertentu.

- $\mathrm{H}_{0}$ diterima jika $\mathrm{t}_{\text {hitung }}<\mathrm{t}_{\text {tabel }}$ : tidak terjadi perubahan yang signifikan pada skor siswa setelah menggunakan media pembelajaran multiplatform.

Tabel 2. Hasil Uji Beda Rata-rata Hasil Belajar Siswa

\begin{tabular}{|l|c|c|l|}
\hline \multicolumn{1}{|c|}{ Perhitungan } & Nilai & \multicolumn{1}{|c|}{ Pembahasan } & \multicolumn{1}{|c|}{ Kesimpulan } \\
\hline $\mathrm{t}$ hitung & 8.889 & $\mathrm{t}$ hitung $>\mathrm{t}$ tabel & $\begin{array}{l}\mathrm{H}_{0} \text { ditolak } \\
\mathrm{H}_{1} \text { diterima }\end{array}$ \\
\hline $\mathrm{t}$ table & 2.028 & & $\begin{array}{l}\mathrm{H}_{0} \text { ditolak } \\
\mathrm{H}_{1} \text { diterima }\end{array}$ \\
\hline Sig.2-tailed & 0.000 & Sig.2-tailed $<\alpha$ & \\
\hline
\end{tabular}

Pada ujicoba perhitungan $\mathrm{t}$ hitung berada pada 8.889 sedangkan untuk t tablenya adalah 2.028. Hal tersebut menunjukkan $t$ hitung lebih besar daripada $t$ tabel, sehingga dapat diambil kesimpulan bahwa terdapat perbedaan signifikan pada hasil belajar kedua kelompok.

\section{Kesimpulan dan Saran \\ 1. Kesimpulan}

Berdasarkan hasil penelitian dan pengembangan ini, dapat disimpulkan hal-hal sebagai berikut:

a Video tutorial pada e-learning IKIP Veteran yang dikembangkan mampu meningkatkan hasil belajar mahasiswa pada mata kuliah Desain Grafis.

b. Mahasiswa memiki tingkat ketertarikan yang tinggi terhada video tutorial yang disematkan pada e-learning IKIP Veteran.

\section{Saran}

Berdasarkan hasil penelitian pengembangan video tutorial, saran penulis adalah sebagai berikut:

a. Ketika akan melaksanakan pembelajaran berbasis multimedia perlu dipastikan terlebih dahulu tentang pengetahuan dasar guru dalam menggunakan multimedia oleh peneliti, dengan harapan proses belajar menjadi efektif.

b. Media pembelajaran yang bersifat multiplatform sebaiknya digunakan juga pada mata pelajaran lainnya sebagai sumber belajar tambahan.

\section{DAFTAR PUSTAKA}

Arikunto, Suharsimi. 2010. Prosedur Penelitian Suatu Pendekatan Praktik. Jakarta: PT. Rineka Putera

Hopper, J.H (2012). Digitize The Easel: Students Perspective on Tutorial Videos in The Art Classroom. Maryland Institute College of Art (MICA): Art Educcation, 69(4) 23-28.

https://www.mica.edu/About_MICA/Departme nts_and_Services/The_Center_for_Art _Education/Art_Education_Research/ Published_Articles.html 
Iqra' al-firdaus. (2010). Buku Lengkap Tuntunan Menjadi Kameramen Profesional. Yogyakarta: Buku Biru

Hebert, R. M., \& Roberts, W. (2013). Online Job Tutorials@the Public Library: Best Practices from Carnegie Library of Pittsburgh's Job \&amp; Career Education Center. Pennsylvania Libraries: Research \& Practice, 1(2), 95-134.

https://doi.org/10.5195/PALRAP.2013 .15

Junus, I. S., Santoso, H. B., Isal, R. Y. K., \& Utomo, A. Y. (2015). Usability evaluation of the student centered elearning environment. International Review of Research in Open and Distributed Learning, 16(4), 62-82. Retrieved from http://www.irrodl.org/index.php/irrodl/ article/view/2175

Ractices, B. E. S. T. P., Nline, F. O. R. O., Bowles-terry, M., \& Hensley, M. K.
(2010). T UTORIALS IN A CADEMIC L IBRARIES A Study of Student Preferences and Understanding, 4(1).

Sugiyono. 2013. Metode Penelitian Kuantitatif Kualitatif Dan R \& D. Bandung: Alfabeta

Suteja, B. R., \& Dkk. (2010). Personalization Sistem E-Learning Berbasis Ontology. MAKARA of Science Series, 14(2), 192-200.

Turner, B., Fuchs, C., \& Todman, A. (2015). Static vs. Dynamic Tutorials: Applying Usability Principles to Evaluate Online Point-of-Need Instruction. Information Technology and Libraries, 34(4), 30. https://doi.org/10.6017/ital.v34i4.5831

Uny, F. T. (2009). Hand out Pengayaan PEMANFAATAN TEKNOLOGI INFORMASI DAN KOMUNIKASI SEBAGAI SUMBER BELAJAR ALTERNATIF, (5), 1-14. 